\title{
EVALUATION OF CARDIAC ENZYMES AND SERUM LIPID PROFILE IN GOATS INFECTED WITH CORYNEBACTERIUM PSEUDOTUBERCULOSIS
}

\author{
AKGUL, G. ${ }^{1}$ and KAHYA DEMIRBILEK, S. $^{2}$ \\ ${ }^{1}$ Siirt University, Faculty of Veterinary Medicine, Department of Internal Medicine, 56100, Siirt, Turkey \\ ${ }^{2}$ Uludağ University, Faculty of Veterinary Medicine, Department of Microbiology, 16059, Bursa, Turkey
}

Received: 20 February 2018; Accepted: 6 March 2018

\begin{abstract}
The aim of the present study was to investigate the prognostic and diagnostic value of cardiac enzymes (creatine kinase-myocardial band (CK-MB), aspartate aminotransferase (AST), and alanine aminotransferase (ALT)) along with a limited lipid profile, including triglycerides (TG), low density lipoproteins (LDL), cholesterol (TCHOL) and high density lipoproteins (HDL), for infection control in goats naturally infected with Corynebacterium pseudotuberculosis (C. pseudotuberculosis). A total of 19 Turkish Hair goats, consisting of 9 healthy goats and 10 goats infected with $C$. pseudotuberculosis, were selected for the study; all goats were between the ages of 1.5-2 years and resided in a special dairy farm. The housing, nutrition and management conditions were the same for all goats. The selection of animals was based on microbiological analyses. A statistically significant difference was observed in the levels of creatine kinase (CK-MB), alanine aminotransferase, alkaline phosphatase, and low-density lipoprotein $(\mathrm{p}<0.05)$ in goats infected with $C$. pseudotuberculosis compared to the control group. In conclusion, this study has demonstrated that goats naturally infected with $C$. pseudotuberculosis have higher levels of cardiac enzymes compared with healthy goats. The prognostic significance of cardiac enzyme levels in goats infected with $C$. pseudotuberculosis deserves further study.
\end{abstract}

Key words: Aspartate aminotransferase, Cholesterol, Creatine kinase-myocardial band, Goat, $C$. pseudotuberculosis.

\section{INTRODUCTION}

Corynebacterium pseudotuberculosis (C. pseudotuberculosis) is the etiological agent of caseous lymphadenitis (CLA), which causes significant economic losses, including a decrease in hair, meat and milk production along with the culling of affected animals, carcasses and skin in slaughterhouses (Paton et al., 1988; Dorella et al., 2006). CLA in sheep and goats is usually associated with the development of large external abscesses in subcutaneous tissues, sub parotid and visceral organs such as the liver, spleen and kidneys (Abdullah et al., 2013; Alonso et al., 1993). CLA has an extraordinarily long incubation period ranging from 3 to 20 weeks. However, shorter incubation periods have been reported (Ashfaq and Campbell, 1979; Johnson et al., 1993) in which only a few animals develop distinct clinical signs; these signs include

Corresponding author: Dr. GÜLŞAH AKGÜL,

E-mail address: gulsahvet@hotmail.com

Present address: Siirt University, Faculty of Veterinary Medicine, Department of Internal Medicine, 56100, Siirt, Turkey. fever and other changes in vital signs such as heart and respiratory rate, inappetence and decreased food consumption, and a change in general health status.

Blood biochemical parameters, serum electrolytes and lipid profiles are very important in diagnosing the disease, monitoring the course of the disease, and following up on the treatment response. These parameters are essential to the diagnosis, treatment and follow-up prognosis. Data regarding the pathogenesis and prognosis of the disease can be obtained from these parameters (Dede et al., 2014).

Levels of circulating enzymes can be useful as an aid in the diagnosis of certain diseases (Eldirdiri et al., 1987). Biochemical analysis of serum can often provide valuable information regarding cardiovascular health and illness in animals (Coodley, 1970). When the myocardium is damaged, the level of enzymes, such as creatine kinase-myocardial band isoenzymes (CK-MB) (Kaneko, 2008), aspartate aminotransferase (AST) and alanine aminotransferase (ALT) (Coodley, 1970), in the serum is elevated. Moreover, cardiac troponin I (cTnI) is a more specific marker than CK-MB for the diagnosis of myocardial 
necrosis (Basbugan et al., 2010); however, the myocardium is one of the richest sources of CK-MB. Therefore, CK-MB is the serum enzyme determinant most widely used for the diagnosis of cardiac diseases in large animals. AST and ALT are not organ-specific and may be of additional value for diagnosing cardiac issues (Coodley, 1970). Therefore, these diagnostic enzymes are valuable tools used in the early detection of cardiac abnormalities resulting from ischemia, injury, or inflammation (Sacher et al., 1991).

Lipoproteins are very large noncellular conglomerates (micelles) of lipids and proteins that are suspended in plasma or lymph. Their main function is to transport most lipids between tissues. Another function of lipoproteins is the esterification of cholesterol. Lipoproteins are classified by their density as determined by ultracentrifugation; the major classes are chylomicrons, very low-density lipoproteins (VLDL), low-density lipoproteins (LDL), and highdensity lipoproteins (HDL).

Although studies have evaluated the interrelationship among CK-MB, ALT and AST in animals (Kozat et al., 2011) and human beings (Polena et al., 2005), no reports have addressed such a probable relationship in goats infected with $C$. pseudotuberculosis. Therefore, the current study aimed to investigate the prognostic and diagnostic value of cardiac enzymes (CK-MB, ALT and AST) and a limited lipid profile, including cholesterol (TCHOL), triglycerides (TG), LDL and HDL, for the control of $C$. pseudotuberculosis infection in goats.

\section{MATERIALS AND METHODS}

\footnotetext{
Animals:

The study was conducted on a single farm. Ten animals with fluctuating, viscous, orange-sized lumps palpable in the right submandibular and/or prescapular lymph nodes were identified, and a creamy, slightly green, malodorous substance was removed by aspiration of the lump. After microscopic examination of colony morphology, biochemical tests were performed according to the characteristics of the suspected bacteria. The isolate was identified as $C$. pseudotuberculosis. These 10 animals comprised the group of $C$. pseudotuberculosis-infected animals $(\mathrm{n}=10)$ in this study. The control group was composed of the other 9 goats $(n=9)$, who demonstrated no loss of appetite, performance, or condition; and were evaluated as healthy by their normal clinical examination results. The examiners were in contact with the animals for approximately 4 hours a day on the goat farm. Ultimately, 19 Turkish Hair goats between the ages of 1.5-2 years were selected for the study. The housing, nutrition and management conditions were the same for all goats.
}

\section{Samples collection and analysis:}

Blood samples from the jugular vein of the animals were collected for serum samples into tubes without anticoagulant. After incubation for 2 hours at room temperature to allow clotting, and centrifugation (at $1500 \mathrm{rpm}$, for 10 minutes, in room temperature), sera were carefully harvested and stored at $-20^{\circ} \mathrm{C}$ until analyzed. The levels of gamma-glutamyl transferase (GGT), creatinine (CRE), alanine aminotransferase (ALT), aspartate aminotransferase (AST), alkaline phosphatase (ALP), glucose (GLU), triglycerides (TG), low-density lipoproteins (LDL), cholesterol (CHOL), high-density lipoproteins (HDL), total proteins (TP), and creatine kinase (CK-MB and CKNAC) were measured by using an automatic analyzer (ADVIA 1800 Clinical Chemistry System).

\section{Microbiological analysis:}

The samples were transferred on dry ice in antibioticfree transport medium (Stuart's medium, Copan, Italy) and submitted to the Microbiology laboratory within 18 hours of collection. Analysis of all samples was initiated immediately after transfer to the laboratory. Culture samples were inoculated onto 5\% sheep blood agar (BBL; 297876), MacConkey agar (BBL; 211387) and Eosin Methylene-blue (EMB) Lactose Saccharose agar (BBL; 221355) and incubated at $37^{\circ} \mathrm{C}$ for $24-72$ hours. Isolated colonies were evaluated according to colony morphology and Gram stain characteristics. For identification of the suspected bacterial colonies, the cultures were analyzed using commercial miniaturized identification systems (BBL Crystal Panel ${ }^{\mathrm{TM}}$ ).

\section{Statistical analysis:}

Descriptive statistics were calculated for each variable. Prior to hypothesis testing, data were analyzed with the Shapiro-Wilk test for normality and Levene's test for homogeneity of variance to ensure that the parametric test assumptions were satisfied. Student's t-test was used to evaluate the difference in CRE, ALT, AST, GLU, TG, LDL, HDL, TP, CK-MB and CK-NAC levels between the healthy controls and the infected group, while the nonparametric MannWhitney U test was used for GGT, ALP and CHOL levels. The level of significance was determined as $\mathrm{p}<0.05$. All statistical analyses were calculated using SPSS version 14.01 statistical software.

\section{RESULTS}

The results of the cardiac enzyme analysis are shown in Table 1. CK-MB and ALT levels were higher in the goats with $C$. pseudotuberculosis compared to the control group $(\mathrm{p}<0.05)$. The serum AST level was higher in the animals of the C. pseudotuberculosis group than in those of the control group, although there was no statistically significant difference between the groups. 
The results of the serum biochemical analysis are shown in Table 2. The ALP level was higher in the goats infected with $C$. pseudotuberculosis compared to the control group $(\mathrm{p}<0.05)$. On the other hand, the levels of GGT, CRE and GLU did not differ between the two groups. The serum CK-NAC level was similar, but the concentration of CK-NAC was higher in the animals of the $C$. pseudotuberculosis group than in those of the control group, although there was no statistically significant difference between the groups.
The results of the serum lipid profile analysis are shown in Table 3. The LDL level was higher in the goats infected with $C$. pseudotuberculosis compared to the control group $(\mathrm{p}<0.05)$. The HDL and CHOL levels were similar, but the concentrations of HDL and CHOL were higher in the animals of the $C$. pseudotuberculosis group than in those of the control group, although there was no statistically significant difference between the groups.

Table 1: Cardiac enzyme levels in healthy goats $(n=9)$ and in goats infected with $C$. pseudotuberculosis $(\mathrm{n}=10)$. The results are expressed as the mean \pm standard error (Mean \pm SE) and Median (Min-Max).

\begin{tabular}{|c|c|c|c|c|c|}
\hline Variable & Group & $\mathrm{n}$ & Mean \pm SE & Median (Min - Max.) & $\mathrm{p}$ \\
\hline \multirow{2}{*}{$\begin{array}{l}\text { ALT } \\
(\mu \mathrm{kat} / \mathrm{L})\end{array}$} & Control & 9 & $0.23 \pm 0.01$ & $0.21(0.18-0.33)$ & \multirow{2}{*}{$<0.001^{*}$} \\
\hline & C. pseudotuberculosis & 10 & $0.34 \pm 0.01$ & $0.34(0.3-0.38)$ & \\
\hline \multirow{2}{*}{$\begin{array}{l}\text { AST } \\
(\mu \mathrm{kat} / \mathrm{L})\end{array}$} & Control & 9 & $1.08 \pm 0.05$ & $1.08(0.85-1.3)$ & \multirow{2}{*}{$0.214^{*}$} \\
\hline & C. pseudotuberculosis & 10 & $1.17 \pm 0.04$ & $1.21(0.98-1.36)$ & \\
\hline \multirow[b]{2}{*}{$\begin{array}{l}\text { CK-MB } \\
(\mu \mathrm{kat} / \mathrm{L})\end{array}$} & Control & 9 & $2.78 \pm 0.43$ & $3.03(0.92-4.57)$ & \multirow[b]{2}{*}{$<0.001$ * } \\
\hline & C. pseudotuberculosis & 10 & $5.43 \pm 0.36$ & $5.99(3.4-6.66)$ & \\
\hline \multicolumn{6}{|c|}{ *According to the Mann-Whitney U test } \\
\hline${ }^{*}$ Accor & udent's t-test & & & & \\
\hline
\end{tabular}

(alanine aminotransferase, ALT; aspartate aminotransferase, AST; creatine kinase-myocardial band, CK-MB)

Table 2: Serum biochemical profiles in healthy goats $(\mathrm{n}=9)$ and in goats infected with $C$. pseudotuberculosis $(\mathrm{n}=10)$. The results are expressed as the mean \pm standard error (Mean \pm SE) and Median (Min-Max).

\begin{tabular}{|c|c|c|c|c|c|}
\hline Variable & Group & $\mathrm{n}$ & Mean \pm SE & Median (Min - Max.) & $\mathrm{p}$ \\
\hline \multirow{2}{*}{$\begin{array}{l}\text { GGT } \\
(\mu \mathrm{kat} / \mathrm{L})\end{array}$} & Control & 9 & $0.79 \pm 0.14$ & $0.7(0.08-1.43)$ & \multirow{2}{*}{$0.986^{*}$} \\
\hline & C. pseudotuberculosis & 10 & $0.79 \pm 0.04$ & $0.77(0.56-1)$ & \\
\hline \multirow{2}{*}{$\begin{array}{l}\text { CRE } \\
(\mathrm{mg} / \mathrm{dL})\end{array}$} & Control & 9 & $0.82 \pm 0.03$ & $0.85(0.68-0.93)$ & \multirow{2}{*}{$0.037^{*}$} \\
\hline & C. pseudotuberculosis & 10 & $0.72 \pm 0.03$ & $0.71(0.6-0.95)$ & \\
\hline \multirow{2}{*}{$\begin{array}{l}\text { ALP } \\
(\mu \text { kat/L) }\end{array}$} & Control & 9 & $1.69 \pm 0.31$ & $1.46(0.83-3.71)$ & \multirow{2}{*}{$0.004^{*}$} \\
\hline & C. pseudotuberculosis & 10 & $2.91 \pm 0.09$ & $2.85(2.4-3.5)$ & \\
\hline \multirow{2}{*}{$\begin{array}{l}\text { GLU } \\
(\mathrm{mg} / \mathrm{dL})\end{array}$} & Control & 9 & $56.56 \pm 2.29$ & $58(46-64)$ & \multirow{2}{*}{$0.898^{*}$} \\
\hline & C. pseudotuberculosis & 10 & $56.1 \pm 2.61$ & $55.5(46-70)$ & \\
\hline \multirow{2}{*}{$\begin{array}{l}\text { CK-NAC } \\
(\mu \mathrm{kat} / \mathrm{L})\end{array}$} & Control & 9 & $2.22 \pm 0.39$ & $2(0.96-4.81)$ & \multirow{2}{*}{$0.271^{*}$} \\
\hline & C. pseudotuberculosis & 10 & $2.68 \pm 0.16$ & $2.61(2.01-3.48)$ & \\
\hline \multirow{2}{*}{$\begin{array}{l}\mathrm{TP} \\
(\mathrm{g} / \mathrm{dL})\end{array}$} & Control & 9 & $7.11 \pm 0.07$ & $7.1(6.8-7.5)$ & \multirow{2}{*}{$0.02^{*}$} \\
\hline & C. pseudotuberculosis & 10 & $7.38 \pm 0.08$ & $7.45(7-7.7)$ & \\
\hline
\end{tabular}

\begin{tabular}{l}
\hline *According to the Mann-Whitney $U$ test \\
\hline *According to Student's t-test \\
\hline (gamma-glutamyl transferase, GGT; creatinine, CRE; alkaline phosphatase, ALP; glucose, GLU; total proteins, TP; creatine \\
kinase, CK-NAC)
\end{tabular}


Table 3: Serum lipid levels in healthy goats and in goats infected with $C$. pseudotuberculosis. The results are expressed as the mean \pm standard error (Mean \pm SE) and Median (Min-Max).

\begin{tabular}{|c|c|c|c|c|c|}
\hline Variable & Group & $\mathrm{n}$ & Mean \pm SE & Median (Min - Max.) & $\mathrm{p}$ \\
\hline \multirow{2}{*}{$\begin{array}{l}\text { TG } \\
(\mathrm{mg} / \mathrm{dL})\end{array}$} & Control & 9 & $30.22 \pm 3.86$ & $31(15-45)$ & \multirow{2}{*}{$0.566^{*}$} \\
\hline & C. pseudotuberculosis & 10 & $27.7 \pm 2.16$ & $29.5(17-37)$ & \\
\hline \multirow{2}{*}{$\begin{array}{l}\mathrm{LDL} \\
(\mathrm{mg} / \mathrm{dL})\end{array}$} & Control & 9 & $215.33 \pm 2.38$ & $215(204-225)$ & \multirow{2}{*}{$<0.001^{*}$} \\
\hline & C. pseudotuberculosis & 10 & $245.3 \pm 2.55$ & $242.5(236-259)$ & \\
\hline \multirow{2}{*}{$\begin{array}{l}\text { CHOL } \\
(\mathrm{mg} / \mathrm{dL})\end{array}$} & Control & 9 & $45.33 \pm 2.79$ & $48(34-56)$ & \multirow{2}{*}{$0.205^{\circ}$} \\
\hline & C. pseudotuberculosis & 10 & $53.9 \pm 3.18$ & $50(45-75)$ & \\
\hline \multirow{2}{*}{$\begin{array}{l}\text { HDL } \\
(\mathrm{mg} / \mathrm{dL})\end{array}$} & Control & 9 & $26.14 \pm 1$ & $26.4(21.2-29.6)$ & \multirow{2}{*}{$0.012^{*}$} \\
\hline & C. pseudotuberculosis & 10 & $29.34 \pm 0.6$ & $29.2(26.3-32.2)$ & \\
\hline \multicolumn{6}{|c|}{$*$ According to the Mann-Whitney U test } \\
\hline
\end{tabular}

(triglycerides, TG; low density lipoprotein, LDL; cholesterol, CHOL, high density lipoproteins, HDL)

\section{DISCUSSION}

The measurement and evaluation of the biochemical profiles may be helpful in elucidating the pathogenesis and prognosis of certain diseases (Șevik et al., 2016). Therefore, this study was designed to investigate the prognostic and diagnostic value of cardiac enzymes (CK-MB, ALT and AST) and a limited lipid profile, including TCHOL, TG, LDL and HDL, for the control of $C$. pseudotuberculosis infection in goats.

The identity of the tissues or organs that are mainly involved when the level of total CK is elevated in the skeletal muscle, heart, brain, and other organs and tissues, to a lesser degree, is not known. However, $\mathrm{CK}$ exists in 3 principal forms, differentiated by the tissue or organ in which it is found. One of these forms, CK-MB, is found predominantly in the heart. CK-MB levels increase under conditions of damage to the heart (Mehran et al.,2000). The other specific cardiac biomarker is cardiac troponin I (Basbugan et al., 2010). Unfortunately, cardiac troponin I was not included in this study.

In the current study, the elevated levels of cardiac enzymes in goats infected with C. pseudotuberculosis compared to healthy control animals indicated possible myocardial injury in the infected animals. CK-MB, AST and ALT are cardiac enzymes used in the diagnosis of heart conditions (Coodley, 1970). Levels of these enzymes were also increased in the serum of goats infected with $C$. pseudotuberculosis compared to healthy control animals, supporting the possibility of cardiac injury. A similar increase in these parameters was reported in lambs affected with white muscle disease (Tunca et al., 2009; Ataollahi et al., 2013). The actual mechanism of cardiac injury in goats infected with $C$. pseudotuberculosis is uncertain. However, to the best of the authors' knowledge, this is the first study addressing the diagnostic and prognostic accuracy of cardiac enzymes (CK-MB, AST and ALT) in cases of $C$. pseudotuberculosis infection in goats.

In addition to being present in hepatocytes, AST is also present in skeletal muscle and cardiac muscle cells. The observed increase in AST level in the infected goats can be related to cardiac injury because the CK-MB level was also increased. However, ALP is an enzyme found in the cells lining the intrahepatic bile ducts, and its concentration increases in biliary disease, intrahepatic cholestasis, and infiltrative diseases of the liver (Lim et al., 2014).We observed a significant increase in ALP concentration in the infected goats. The levels of both ALP and GGT have been reported to be elevated in cholestasis (Whitfield et al., 1972). In the current study, no significant difference in GGT level between the infected and control groups was observed. Therefore, the increase in the level of ALP in goats infected with $C$. pseudotuberculosis can be related to hepatic injury.

The liver is the most important organ in the metabolism of lipids and lipoproteins, and under normal conditions, most of the lipids and lipoproteins in the plasma are synthesized through the cellular functions of the liver and are released into the bloodstream (Bell, 1979; Tietge et al.,1998). From this point of view, the presence of certain lipids and lipoproteins in the plasma could be expected to contribute to the development of hepatic damage (Wang et al 2008). The results presented in the current study showed that the LDL level was 
significantly increased in the goats infected with $C$. pseudotuberculosis compared to healthy controls (Table 3). Although the levels of HDL and CHOL were high, no statistically significant difference was found for either enzyme between the groups. In addition, TG levels were normal. The increased LDL, HDL and cholesterol levels found in the current study may be due to impaired lipid metabolism in the infected goats. Lipoproteins are the subject of extensive research in human medicine, especially in relation to the diagnosis of diseases of the cardiovascular system, but lipoprotein analysis is infrequently requested in domestic animals (Kaneko et al., 2008). Increased levels of LDL and decreased levels of HDL are also indicative of an increased incidence of cardiac events and are considered cardiovascular risk factors. Therefore, in this study, the relationship between lipid profile parameters and cardiac events was evaluated. The levels of both CKMB and LDL in goats infected with $C$. pseudotuberculosis were higher compared to the control group $(\mathrm{p}<0.05)$.

\section{CONCLUSION}

In conclusion, these results suggest that goats naturally infected with $C$. pseudotuberculosis have higher levels of cardiac enzymes compared with healthy goats. To the authors' knowledge, no study has been performed previously using cardiac enzyme levels for the diagnosis of cardiac injury in goats infected with $C$. pseudotuberculosis. However, further studies, especially long-term or histological evaluations, are required to characterize more accurately the putative cardiotoxicity in goats naturally infected with C. pseudotuberculosis.

\section{REFERENCES}

Abdullah, F.F.J; Osman, A.Y.; Adamu, L.; Azri, N.A. and Wahid, A. (2013): Caseous lymphadenitis in a goat. Vet. J., 52: 513-514.

Alonso, J.L.; Simon, M.C.; Girones, O.; Muzquiz, J.L.; Ortega, C. and Garcia, J. (1993): The effect of experimental infection with Corynebacterium pseudotuberculosis on reproduction in adult ewes. Res. In. Vet. Sci., 52: 267- 272.

Ashfaq, M.K. and Campbell, S.G. (1979): A survey of caseous lymphadenitis and its etiology in goats in the United States. Vet. Med. Sm. Anim. Clin., 74: 1161-1165.

Ataollahı, F.; Mohrl, M. and Selfi, H.A. (2013): Diagnostic value of cardiac troponin I (cTnI), creatine kinase $(\mathrm{CK})$, and aspartate amino transferase (AST) in selenium deficiency in lambs. Revue. Méd. Vét.,164: 207-211.

Basbugan, Y.; Agaoglu, Z. and Yüksek, N. (2010): An investigation on serum troponin concentration in healthy ruminants. Kafkas. Univ. Vet. Fak. Derg., 16: 641-645.

Bell, A.W. (1979): Lipid metabolism in liver and selected tissues and in the whole body of ruminant animals. Prog. Lip. Res., 18: 117164.

Coodley, E.L. (1970): Diagnosic Enzymology. WB. Saunders Co, Philadelphia, USA, Pp 120-125.

Dede, S.; Altuğ, N.; Değer, Y. and Özdal, N.E. (2014): Serum biochemical profile and protein fractions in cattle with Theileriosis. Revue. Méd. Vét., 165:137-143.

Dorella, F.A.; Pacheco, L.G.C.; Oliveira, S.C.; Miyoshi, A. and Azevedo, V. (2006): Corynebacterium pseudotuberculosis: microbiology, biochemical properties, pathogenesis and molecular studies of virulence. Vet. Res. 37; 201-218.

Eldirdiri, N.I.; Suliman, H.B. and Shommein, A.M. (1987): Normal serum activities of some diagnostic enzymes in dromedary camel in Sudan. Vet. Res. Commun., 11:201-203.

El-Sherif, M.M.A. and Assad, F. (2001): Changes in some blood constituents of Barki ewes during pregnancy and lactation under semi arid conditions. Small. Rumin. Res., 40: 269-277.

Johnson, E.H.; Vidal, C.E.S.; Santa, R.J. and Kass, P.H. (1993): Observations on goats experimentally infected with Corynebacterium pseudotuberculosis. Small. Rumin. Res., 12:357-369.

Kaneko, J.J.; Harvey, J.W. and Bruss, M.L. (2008): Clinical biochemistry of domestic animals. Newyork USA, Academic press.

Lim, T.K. (2014): Edible Medicinal and Non Medicinal Plants, Springer, London,UK.

Mehran, R.; Dangas, G.; Mintz, G.S.; Lansky, A.J.; Pichard, A.D.; Satler, L.F.; Kent, K.M.; Stone, G.W. and Leon, M.B.(2000): Atherosclerotic plaque burden and CK-MB enzyme elevation after coronary interventions. Circulation., 101: 604-610.

Paton, M.W.; Mercy, A.R.; Wilkinson, F.C.; Gardner, J.J.; Sutherland, S.S. and Ellis, T.M. (1988): The effects of caseous lymphadenitis on wool production and body weight in young sheep. Aust. Vet. J., 65; 117-119.

Sacher, R.A.; Mcpherson, R.A. and Campos, J.M. (1991): Widmann's Clinical Interpretation of Laboratory Tests, FA. Davis Company, Philadelphia, USA

Şevik, M.; Avci, O.; Doğan, M. and Ince, Ö.B. (2016): Serum Biochemistry of Lumpy Skin Disease Virus-Infected Cattle. Bio Med. Research. International.

Tietge, U.J.; Boker, K.H. and Bahr, M.J. (1998): Lipid parameters predicting liver function in patients with cirrhosis and after liver transplantation. Hepato-gastroenterol., 45: 2255-2260. 
Tunca, R.; Erdoğan, H.M.; Sozmen, M.; Citıl, M.; Devrım, A.K.; Erginsoy, $S$. and Uzlu, E. (2009): Evaluation of Cardiac Troponin I and Inducible Nitric Oxide Synthase Expressions in Lambs with White Muscle Disease.Turk. J. Vet. Anim. Sci., 33: 53-59.

Wang, C.C.; Cheng, P.Y.; Peng, Y.C.; Wu, E.S.; Wei, H.P. and Yen, M.H. (2008): Naltrexone protects against lipopolysaccharide/Dgalactosamine - induced hepatitis in mice. J. Pharmacol. Sci., 108: 239-247.
Whitfield, J.B.; Pounder, R.E.; Neale, G. And Moss, D.W. (1972): Serum $\gamma$-glutamyl trans peptid a seactivity in liver disease,"Gut.,vol.13, Pp.702-708.

Van Knegsel, A.T.M.; Van Den Brand, H.; Dijkstra, J.; Van Straalen, W.M.; Jorritsma, R.; Tamminga, S. and Kemp, B. (2007): Effect of glucogenic vs. lipogenic diets on energy balance, blood metabolites, and reproduction in primiparous and multiparous dairy cows in early lactation. J. Dairy. Sci., 90: 3397- 3409. 